\title{
Mitigation actions performed to the remediation of groundwater contamination by arsenic in drinking water sources in Chihuahua, Mexico
}

\author{
M.A. Olmos-Marquez ${ }^{1,2}$, C.G. Sáenz-Uribe ${ }^{1}$, J.M. Ochoa-Riveros ${ }^{4}$, \\ A. Pinedo-Alvarez ${ }^{1} \&$ M.T. Alarcón-Herrera ${ }^{3}$ \\ ${ }^{1}$ Universidad Autónoma de Chihuahua, Chihuahua, Chih., Mexico \\ ${ }^{2}$ Junta Municipal de Agua y Saneamiento, Chihuahua, Chih., Mexico \\ ${ }^{3}$ Centro de Investigación Materiales Avanzados (Sede Chihuahua), Chihuahua, Chih., Mexico \\ ${ }^{4}$ Sitio Experimental la Campana, CIRNOC, Instituto Nacional de Investigaciones Forestales, Agricolas y Pecuarias \\ (INIFAP), Aldama, Chih., Mexico
}

\begin{abstract}
In this work, current information about the contamination of groundwater by arsenic (As) from geogenic sources in Chihuahua state, Mexico is presented together with a possible emerging mitigation solution. The problem in Chihuahua is of the same order of magnitude as other world regions, such as Argentina. Despite the studies undertaken by numerous local researchers, and the identification of proven treatment methods for the specific water conditions encountered, no technologies have been commercialized to treat reject water from the Reverse Osmosis System (ROS). The use of constructed wetlands like an emerging, low-cost technologies to mitigate the problem of As in reject water from ROS that are installed for rural and urban areas have been evaluated. This technology generally use simple and low-cost equipment that can easily be handled and maintained by the local population and the water obtained can be used to irrigation of some crops, resulting in a benefit to community.
\end{abstract}

\section{INTRODUCTION}

Arsenic contaminations of groundwater in several parts of the world are the results of natural and/or anthropogenic sources and have a large impact on human health (Geschwind et al., 1992). Millions of people from different countries rely on groundwater containing As for drinking purposes (Mondal et al., 2013; Olmos-Márquez et al., 2011). A great amount of communities in Chihuahua extract groundwater for domestic water uses, and many communities are entirely dependent on groundwater. Chihuahua groundwater generally contains As in concentrations above the Mexican regulation $\left(25 \mu \mathrm{g} \mathrm{L}^{-1}\right)$. Therefore, the institution in charge of drinking water supply in Chihuahua, Junta Central de Agua y Saneamiento, (JCAS for its Spanish acronym), has exigent implications for the provision of safe drinking water in Chihuahua. To put the arsenic impact on Chihuahua State into perspective, the total number of municipalities affected by As presence in groundwater represents roughly $75 \%$. Since the beginning of the year 2000 the JCAS, has been working to reduce exposure to As by drinking water and foods consumption, in the communities affected by As occurrence, installing a large number of reverse osmosis system and development innovative projects to treat the reject water.

\section{SITUATION OF GROUNDWATER CONTAMINATION BY ARSENIC IN CHIHUAHUA STATE}

\subsection{Description of the study area}

Chihuahua state is located in the north of Mexico, its conformed by 67 municipalities, with a surface of $247,460 \mathrm{~km}^{2}$ and a population of $3,556,574$ inhabitants, which is the biggest state of Mexico. A $60 \%$ from the water used in the state comes from groundwater sources.

\subsection{Arsenic distribution in groundwater}

50 of the 67 municipalities from Chihuahua State have at least one of its groundwater supply with arsenic concentrations above the Mexican drinking water regulation. 24 municipalities have more than $50 \%$ of its sources of drinking water out of normative. The municipalities with the highest arsenic concentration are: Julimes, Camargo, Jimenes, Delicias, Valle de Zaragoza, Meoqui, La Cruz, Saucillo, Rosales and San Francisco de Conchos. The average As concentrations in these areas are between 25 and $910 \mu \mathrm{g} \mathrm{L}^{-1}$ (Fig. 1). 


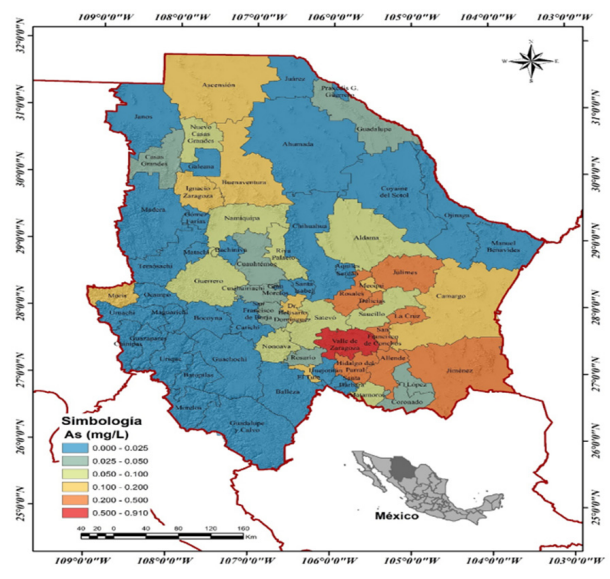

Figure 1. Arsenic groundwater concentrations in Chihuahua state.

3 CURRENT STATUS OF REMEDIATION EFFORTS MAKE BY CHIHHUAHUA STATE GOVERNMENT FOR SOLVE THE PROBLEMS WITH ARSENIC IN DRINKING WATER

\subsection{Mitigation actions to provide arsenic free drinking water}

The government of the State of Chihuahua, Mexico through the JCAS has undertaken several actions to respond to the high levels of As in the water sources. Since year 2000 there have been installed 370 systems of reverse osmosis in 50 of the affected municipalities that have As concentration above the safe standards marked in the Mexican Norm (NOM-127-SSA12000). The population benefited for the program is of 720,176 inhabitants scattered in 309 communities. The investments was of 93,612,385 MeX\$ (5,200,688 USD). However, there is a large percentage $(50 \%)$ on the reject stream that is not been disposed accordingly. To reduce this percentage the Universidad Autónoma de Chihuahua in cooperation with the Board Commission for Water are developing a technology that allows to reduce the As in the reject stream that was a volume $1,480,000 \mathrm{~L} \mathrm{day}^{-1}$, and thus make that water available for other uses such agricultural irrigation, family and municipal gardens, among others.

\subsection{Constructed wetlands pilot plant}

A pilot-level system was designed and built in Julimes municipality $\left(28^{\circ} 25^{\prime} 25^{\prime \prime} \mathrm{N} ; 105^{\circ} 25^{\prime} 32^{\prime \prime} \mathrm{W}\right)$ which has the one of the highest As concentrations in the state $\left(488 \mu \mathrm{g} \mathrm{L}^{-1}\right)$. The system is located inside a greenhouse of $10 \mathrm{~m} \times 5 \mathrm{~m} \times 3 \mathrm{~m}$ and consists of two fiberglass constructed wetlands (CWs) with dimensions of $4.5 \mathrm{~m} \times 1.5 \mathrm{~m} \times 0.70 \mathrm{~m}$. The CWs were filled with silty sand up to $0.50 \mathrm{~m}$ and planted with Schoenoplectus americanus and Elleocharys macrsotachya. The average As concentration of the ROS reject water (feed water of CWs) is in the range of $300 \mu \mathrm{g} \mathrm{L}^{-1}$, the average water flow treated is $1400 \mathrm{~L} \mathrm{~d}^{-1}$ with a residence

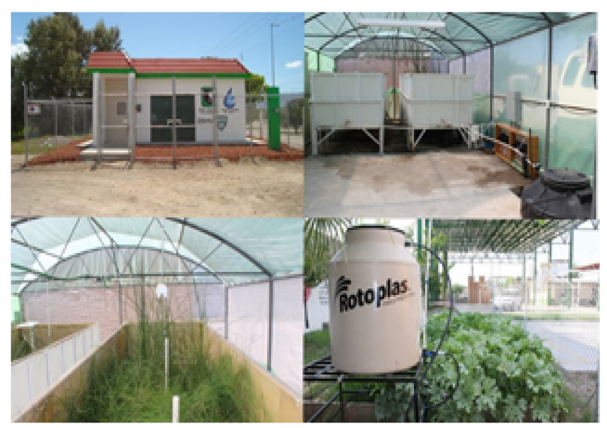

Figure 2. Pilot system implemented to remove arsenic from reject water of reverse osmosis system through constructed wetlands in Julimes, Chihuahua Mexico.

time of $2 \mathrm{~d}$. Water treated by the wetland system is collected and pumped to an $800 \mathrm{~L}$ water storage tank, for use in the irrigation of a small family orchard (Fig. 2). The system has removal As efficiencies of 85$99 \%$ and the operation and maintenance cost is very low, because it only uses a pump of $0.5 \mathrm{hp}$ to pump the water and the rest of the hydraulic process is by gravity, the system should be supervised only once week. It is important to mention that if this water is not treated it implies some risks to health and environment.

\section{CONCLUSIONS}

The state of Chihuahua has a serious impact by As in drinking water, the state government has taken actions to provide safe water to the inhabitants of the affected communities, installing inverse osmosis plants. However, it is necessary to solve the problem of adequate disposition of the reject water generated by reverse osmosis systems. Constructed wetlands have proven to be a viable and economical option to solve this problem, as well as to provide a reuse capacity of treated water in activities that economically benefit the communities where these systems are installed.

\section{ACKNOWLEDGEMENTS}

This work was financially supported by National Council for Science and Technology (CONACYT), within the Program Attention to National Problems.

\section{REFERENCES}

Geschwind, S.A., Stolwijk, J.A., Bracken, M., Fitzgerald, E., Stark, A., Olsen, C. \& Melius, J. 1992. Risk of congenital malformations associated with proximity to hazardous waste site. Am. J. Epidemiol. 135(11), 1197-1207.

Mondal, P., Bhowmick, S., Chatterjee, D., Figoli, A. \& Van der Bruggen, B. 2013. Remediation of inorganic arsenic in groundwater for safe water supply: a critical assessment of technological solution. Chemosphere 92(2): 157-170.

Olmos-Márquez, M.A., Alarcón-Herrera, M.T. \& MartinDomínguez, I.R. 2011. Performance of Eleocharys macrostachya and its importance for arsenic retention in constructed wetlands. Environ. Sci. Pollut. R. 19(3): 763-771. 